\title{
Capabilities of Pure Culture of Bacteria in the Biodegradation of Polycyclic Aromatic Hydrocarbons and Total Petroleum Hydrocarbons in Oilfield Wastewater
}

\author{
O. Aleruchi* and O. Obire
}

Department of Microbiology, Rivers State University, P.M.B 5080, Port Harcourt, Nigeria

*Corresponding author

\section{Keywords}

Polycyclic aromatic hydrocarbon, Total petroleum hydrocarbon, Oilfield wastewater, Biodegradation, Gas chromatography

Article Info

\section{Accepted:}

18 March 2021

Available Online: 10 April 2021

\section{A B S T R A C T}

Polycyclic aromatic hydrocarbons (PAHs) and total petroleum hydrocarbons (TPHs) in oilfield wastewater are of environmental importance because of its negative impact in the environment where they are discharged. Therefore it is important to efficiently treat oilfield wastewater before its discharge into the environment. This study therefore investigated the capabilities of pure cultures of bacteria in the biodegradation of polycyclic aromatic hydrocarbons (PAHs) and total petroleum hydrocarbons (TPHs) in oilfield wastewater. Standard procedures where observed in the collection of oilfield wastewater samples and its investigations. The bacteria used for the study were isolated from soil enriched with oilfield wastewater. Four bacteria isolates were molecularly identified using 16S rRNA method as Morganella morganii (MN094330), Pseudomonas xiamenensis (MN094331), Chryseobacterium cucumeris (MN094332) and Staphylococcus sp (MN094333). Each biodegradation experimental $250 \mathrm{ml}$ flask contained $125 \mathrm{ml}$ of oilfield wastewater (ofww) and $6.25 \mathrm{ml}(5 \%)$ of the bacteria culture. The control contained only the ofww $(125 \mathrm{ml})$. The set up were placed in a shaker incubator at $28^{\circ} \mathrm{C}$ with $200 \mathrm{rpm}$ for aeration. The experimental samples were periodically analyzed at day 1 , 7 and 21 intervals for PAHs and TPHs using Gas chromatography (GC). The initial total amount of PAHs and TPHs in the oilfield wastewater on day 1 was $101.72992 \mathrm{mg} / \mathrm{l}$ and $342.89053 \mathrm{mg} / \mathrm{l}$, respectively. At the end of the experiment (day 21), the treatment with Pseudomonas xiamenensis recorded the least remaining of $22.23959 \mathrm{mg} / \mathrm{l}$ of PAHs with $78.1 \%$ removal while the control recorded the highest remaining of $75.40663 \mathrm{mg} / \mathrm{l}$ of PAHs remaining with $25.9 \%$ removal. There was complete absence of Chrysene in the treatments with Pseudomonas xiamenensis, Staphylococcus sp and Chryseobacterium cucumeris. There were reductions in the peaks of the various PAHs on day 21 in all the treatments. The least and highest amount of TPHs remaining on day 21 was observed in the Chryseobacterium cucumeris $(58.18741 \mathrm{mg} / \mathrm{l})$ and control $(240.74905 \mathrm{mg} / \mathrm{l})$, respectively with percentage removal of $84.8 \%$ and $36.9 \%$, respectively. The treatment with Morganella morganii on day 21 showed total clearance of $\mathrm{C}_{12}, \operatorname{Pr}, \mathrm{C}_{22}$ and $\mathrm{C}_{26}$. After 21 days of treatment, Pseudomonas xiamenensis showed removal of $\mathrm{C}_{12}, \mathrm{C}_{19}, \mathrm{C}_{22}$ and $\mathrm{C}_{26}$. Staphylococcus sp recorded removal of $\mathrm{C}_{12}, \mathrm{Pr}, \mathrm{C}_{19}, \mathrm{C}_{20}, \mathrm{C}_{22}$ and $\mathrm{C}_{26}$. Chryseobacterium cucumeris completely removed $\mathrm{C}_{10}, \mathrm{C}_{12}, \mathrm{Pr}, \mathrm{C}_{19}, \mathrm{C}_{20}, \mathrm{C}_{22}, \mathrm{C}_{23}$ and $\mathrm{C}_{26}$. At the end of the experiment, the ability of the individual bacterium to biodegrade PAHs and TPH were revealed by Gas chromatography (GC). However, some organisms' biodegraded PAHs faster than TPH and vis versa. 


\section{Introduction}

Hydrocarbons are a ubiquitous family of several chemically related environmental importunate organic compounds of various structures and with different levels of toxicity. Oilfield wastewater generated by petrochemical industries are characterized by the presence of large quantity of polycyclic and aromatic hydrocarbons, phenols, metal derivatives, surface active substances, sulphides, naphthylenic acids and other chemicals (Aleruchi and Obire, 2018; Suleimanov, 1995). Due to the ineffectiveness of purification systems, wastewater may become dangerous, leading to the accumulation of toxic products in the soil or receiving water bodies with potentially serious consequences on the ecosystem (Bay et al., 2003). Crude oil is a complex mixture of several polycyclic aromatic compounds and other hydrocarbons.

The major hydrocarbon classes found in crude oil are the normal alkanes which are easily degraded, branched alkanes and cycloalkanes, (difficult to identify), the isoprenoids (very resistant to biodegradation), the aromatics (fairly identified and much more soluble than other hydrocarbons), and finally the polar ones containing mainly sulphur, oxygen and/or nitrogen compounds. Non hydrocarbon compounds may also be found in crude oil and they include porphyrins and their derivatives (Callot and Ocampo, 2000). Bioremediation can be applied as green technologies which are environmentally friendly and cost effective response to oil pollution. In recent years, there has been increasing interest in developing cost effective in-situ technique for bioremediation of oil contaminated sites. Three main approaches of this technique: natural attenuation (reliance on natural biodegradation activities and rates), which is sometimes called intrinsic bioremediation; biostimulation (stimulation of natural activities by environmental modification such as fertilizer addition to increase rates of biodegradation); and bioaugmentation (addition of exogenous microorganisms to supplant the natural degradative capacity of the hydrocarbonimpacted ecosystem) (Kaplan and Kitts 2004; Prince and Atlas 2005; Chikere et al., 2009a, b; Gertler et al., 2009a). Microorganisms are the major agents in the degradation of petroleum hydrocarbons. The organisms include bacteria, yeast, filamentous fungi and algae (Prince, 1993; Atlas, 1981).

The principal bacteria and fungi genera responsible for oil degradation in both soils and aquatic environment have been identified as comprising mainly Pseudomonas, Achrobacter, Bacillus, Micrococcus, Nocardia, Trichoderma, Penicillium, Aspergillus and Morteilla (Atlas, 1981; Bossert and Bartha, 1984; Okpokwasili and Amanchukwu, 1988). This study therefore compares the potentials of individual isolates in the biodegradation of polycyclic aromatic hydrocarbons and total petroleum hydrocarbon in an oilfield wastewater.

\section{Materials and Methods}

\section{Sample Collection and Isolation}

Oilfield wastewaters were collected from Ogbugu flow station; an onshore oil production platform located in Ogba/Egbema/Ndoni local government Area (ONELGA) of Rivers State, Nigeria. The Oilfield wastewater samples were collected using 4 Litre capacity sterile sample bottles and stored in an ice packed cooler. The soil samples were collected 80 meters away from the discharge pond at a depth of $0-15 \mathrm{~cm}$ with a clean hand auger into sterile polythene bags and stored in an ice packed cooler. The collected oilfield wastewater and soil samples were immediately transported to the laboratory for analysis within 24 hours. 
Bacteria were isolated from the soil $(100 \mathrm{~g}$ each) enriched with various concentrations $(10 \%, 25 \%, 50 \%, 75 \%)$ of oilfield wastewater. The enriched soil sample was incubated in a rotary shaker incubator at $28^{\circ} \mathrm{C}$ with $200 \mathrm{rpm}$ for aeration and withdrawn seven (7) days interval for analyses.

\section{Preparation of Enriched Soil Sample Inoculum}

One gram (1g) of the enriched soil samples were serially diluted onto $9 \mathrm{ml}$ of sterile normal saline in a test tube to give an initial dilution of 1:10 $\mathrm{ml}\left(10^{-1}\right.$ dilution). Subsequent dilutions were done up to $10^{-3}$ dilution (Prescott et al., 2005).

\section{Isolation of Bacteria}

Isolation of heterotrophic bacteria was done using nutrient agar by the spread plate technique as described by Prescott et al., (2005). Aliquots $(0.1 \mathrm{ml})$ of serially diluted samples of $10^{-2}$ dilution were spread plated onto dried sterile nutrient agar plates in duplicates. The plates were incubated at $37^{\circ} \mathrm{C}$ for 24 hours. Representative colonies were selected and sub-cultured to purify them into pure isolates for characterization. The purified colonies represented the bacteria isolated from the enriched soil samples. The individual isolate were labeled OA1, OA2, OA3 and OA4.

\section{Molecular Identification of Bacterial Isolates}

The 16S rRNA regions of the rRNA gene of the isolates (OA1-OA4) were amplified after extraction and quantification of the DNA using the 27F: 5'-AGAGTTTGAT CMTGGCTCAG-3' and 1492R: 5'-CGGTT ACCTTGTTACGACTT-3' primers on an ABI 9700 Applied Bio systems thermal cycler at a final volume of 40 microlitres for 35 cycles.
The PCR mix included: the X2 Dream taq Master mix supplied by Inqaba, South Africa (taq polymerase, DNTPs, $\mathrm{MgCl}$ ), the primers at a concentration of $0.5 \mu \mathrm{M}$ and the extracted DNA as template. The PCR conditions were as follows: Initial denaturation, $95^{\circ} \mathrm{C}$ for 5 minutes; denaturation at $95{ }^{\circ} \mathrm{C}$ for 30 seconds; annealing at $52^{\circ} \mathrm{C}$ for 30 seconds; extension at $72{ }^{\circ} \mathrm{C}$ for 30 seconds for 35 cycles and final extension at $72^{\circ} \mathrm{C}$ for 5 minutes. The product was resolved on a $1 \%$ agarose gel at $130 \mathrm{~V}$ for 30 minutes and visualized on a blue light transilluminator.

The sequences of the isolates were edited using the bioinformatics algorithm Trace edit; similar sequences were downloaded from the National Center for Biotechnology Information (NCBI) data base using BLASTN and was further aligned using ClustalX. The evolutionary history was inferred using the Neighbour-Joining method in MEGA 6.0 (Saitou and Nei, 1987). The bootstrap consensus tree inferred from 500 replicates (Felsenstein, 1985) was taken to represent the evolutionary history of the taxa analysed. The evolutionary distances were computed using the Jukes-Cantor method (Jukes and Cantor, 1969). The identified isolates were submitted to the Gene bank and were assigned accession numbers.

\section{Biodegradation Experiment}

The experiment was designed to analyze the potential of the selected organisms to biodegrade polycyclic aromatic hydrocarbons (PAHs) and total petroleum hydrocarbon in oilfield wastewater using Gas Chromatograph.

\section{Preparation of Inoculum}

The microbial inocula consisted of indigenous organisms (HUB) obtained earlier from the study of enrichment of various concentration of oilfield wastewater on soil microorganisms. 
The method described by El-Borai et al., (2016) was adopted. Bacteria were sub cultured on a sterile nutrient agar and incubated for 24 hours at $37{ }^{\circ} \mathrm{C}$. A loopful of each bacterium isolates (OA1- OA4) were inoculated into $4 \mathrm{ml}$ nutrient broth medium at $35{ }^{\circ} \mathrm{C}$ for activation of the organisms for biodegradation. The different strains from overnight cultures at the log phase of growth were transferred to $250 \mathrm{ml}$ conical flasks each containing $50 \mathrm{ml}$ of sterile defined mineral salts medium (MSM) for 24 hours at $35{ }^{\circ} \mathrm{C}$ in a shakers incubator. The bacterial suspension turbidity was adjusted to 0.5 McFarland standards $\left(1.5 \times 10^{8}\right)$.

\section{Composition of Biodegradation Set up}

The biodegradation experimental set up was made up of five conical flasks $(250 \mathrm{ml})$ each, labeled A1 to A5 (Table 1). Each flask contained $125 \mathrm{ml}$ of oilfield wastewater (ofww) and $6.25 \mathrm{ml} \mathrm{(5 \% )} \mathrm{of} \mathrm{the} \mathrm{bacteria}$ culture. The set up were placed in a shaker incubator at $28^{\circ} \mathrm{C}$ with $200 \mathrm{rpm}$ for aeration and were as presented on Table 1 .

\section{Results and Discussion}

Figure 1 shows the phylogenetic tree and the evolutionary relationship of the individual isolates. The isolates labelled OA1 to OA4 showed $100 \%$ relatedness to their relatives in the gene bank and were assigned accession numbers. The isolates labelled OA1, OA2, OA3 and OA4 were identified as Morganella morganii (MN094330), Pseudomonas xiamenensis (MN094331), Chryseobacterium cucumeris (MN094332) and Staphylococcus sp (MN094333), respectively.

Figure 2 shows the initial concentration of the PAHs and the biodegradation by the single bacterium. On day 7 Chryseobacterium cucumeris recorded the least remaining while the control recorded the highest remaining. On day 21 Pseudomonas xiamenensis showed the least remaining.

The concentration of the PAHs on the initial was $101.72992 \mathrm{mg} / \mathrm{l}$. The treatment option containing Pseudomonas xiamenensis had the least amount of $22.23959 \mathrm{mg} / \mathrm{l}$ remaining on day 21 with removal of $78.1 \%$, which was followed by the treatment option with Staphylococcus $s p$ which recorded remaining of $27.31228 \mathrm{mg} / \mathrm{l}$ with $73.2 \%$ removal, Chryseobacterium cucumeris had 34.98499 $\mathrm{mg} / \mathrm{l}$ remaining with $65.6 \%$ removal and Morganella morganii recorded $35.50295 \mathrm{mg} / \mathrm{l}$ remaining with $65.1 \%$ removal. The control had the highest amount of $75.40663 \mathrm{mg} / \mathrm{l}$ remaining with $25.9 \%$ removal at the end of the experiment (Table 2).

The GC profile in Figure 3 (day 1) showed the presence of Naphthalene, Acenephthylene, Acenaphthene, Anthracene and Chrysene. The control and treatment with Morganella morganii did not show any clearance of the individual polycyclic aromatic hydrocarbons on day 21 (Figures 4 and 5). There was complete absence of Chrysene on day 21 in the treatments with Pseudomonas xiamenensis, Staphylococcus sp and Chryseobacterium cucumeris as shown in the GC (Figures 6, 7 and 8). There were reductions in the peaks of the various polycyclic aromatic hydrocarbons on day 21 in all the treatments.

The results in Figure 9 showed the concentration of the total petroleum hydrocarbon on day 1, 7 and 21 . On day 7 , the Staphylococcus sp, treated sample recorded the highest remaining while the least remaining was observed in the Chryseobacterium cucumeris. The highest and least remaining on day 21 was observed in control and Chryseobacterium cucumeris, respectively. Table 3 showed the initial, final concentration and the percentage removal of 
the treatment options. The initial concentration on day 1 was $342.89053 \mathrm{mg} / \mathrm{l}$. The final concentration recorded on day 21 for the control was $240.74905 \mathrm{mg} / \mathrm{l}$ with $36.9 \%$ percentage removal. Morganella morganii recorded remaining of $129.47221 \mathrm{mg} / \mathrm{l}$ with $66.1 \%$ removal. Pseudomonas xiamenensis on final day recorded $119.29648 \mathrm{mg} / \mathrm{l}$ and obtained percentage removal of $68.8 \%$. Staphylococcus sp recorded $85.04915 \mathrm{mg} / \mathrm{l}$ on day 21 with $77.7 \%$ percentage removal. Chrysebacterium cucumeris recorded final concentration of $58.18741 \mathrm{mg} / \mathrm{l}$ with percentage removal of $84.8 \%$.

The GC profiles of the various treatments are shown in Figure 9, 10, 11, 12, 13 and 14.

Figure 9 show the individual n-alkanes and their peaks on day 1 . The n-alkanes recorded were $\mathrm{C}_{8}, \mathrm{C}_{9}, \mathrm{C}_{10}, \mathrm{C}_{12}, \mathrm{C}_{14}, \mathrm{C}_{15}, \mathrm{Pr}, \mathrm{C}_{18}, \mathrm{C}_{19}$, $\mathrm{C}_{20}, \mathrm{C}_{22}, \mathrm{C}_{23}$ and $\mathrm{C}_{26}$. Figure 10 showed the GC of the control on day 21, there was no clearance of n-alkanes as observed. Figure 11 showed the GC profile of the treatment with Morganella morganii on day 21, there was total clearance of $\mathrm{C}_{12}, \operatorname{Pr}, \mathrm{C}_{22}$ and $\mathrm{C}_{26}$. Treatment with Pseudomonas xiamenensis on day 21 showed removal of $\mathrm{C}_{12}, \mathrm{C}_{19}, \mathrm{C}_{22}$ and $\mathrm{C}_{26}$ as shown in Figure 12. Staphylococcus $\mathrm{sp}$ treatment option on day 21 recorded removal of $\mathrm{C}_{12}, \mathrm{Pr}, \mathrm{C}_{19}, \mathrm{C}_{20}, \mathrm{C}_{22}$ and $\mathrm{C}_{26}$ as shown in Figure 13. Treatment option with Chryseobacterium cucumeris as shown in Figure 14 completely removed $\mathrm{C}_{10}, \mathrm{C}_{12}, \mathrm{Pr}$, $\mathrm{C}_{19}, \mathrm{C}_{20}, \mathrm{C}_{22}, \mathrm{C}_{23}$ and $\mathrm{C}_{26}$. Generally there was reduction in the level of peaks.

Microorganisms obtained from hydrocarbon polluted environment have been known to be efficient in using hydrocarbons as carbon and energy sources (Obire et al., 2020; Aleruchi and Abu, 2015; Cui et al., 2008). The results clearly showed that the bacteria isolates were capable of growing in hydrocarbon polluted environment as they were isolated from soil enriched with oilfield wastewater. Bacteria isolate showed $100 \%$ relatedness to their relatives in the gene bank. Microorganisms capable of utilizing hydrocarbon are widely distributed in nature and have been found in areas not directly contaminated with hydrocarbon (Yousseff et al., 2010).

The biodegradative capabilities of the single isolates to biodegrade polycyclic aromatic and total petroleum hydrocarbons were compared. For polycyclic aromatic hydrocarbon, Chryseobacterium cucumeris recorded the least remaining on day 7 , this was followed by Staphylococcus sp, Morganella morganii, Pseudomonas xiamenensis and control. Pseudomonas xiamenensis on day 21 had the least remaining and the highest percentage removal, followed by Staphylococcus sp, Chryseobacterium cucumeris, Morganella morganii and the control. The results indicate that some organisms have different strategy they use to attack polycyclic aromatic hydrocarbon, while some may attack faster, some slowly. This was seen in the case of treatment with Pseudomonas xiamenensis which had highest remaining concentration of polycyclic aromatic hydrocarbon among the treatment options on day 7 but on day 21 it recorded the least remaining, Chryseobacterium cucumeris and Morganella morganii reduced in its degradation rate after day 7. Staphylococcus sp maintained its degradation rate. The control recorded the highest remaining concentration of polycyclic aromatic hydrocarbons on day 21. The Gas Chromatography on day 21 showed total clearance of chrysene by Pseudomonas xiamenensis, Staphylococcus sp and Chyrseobacterium cucumeris. 
Table.1 Biodegradation Set up

\begin{tabular}{|c|c|}
\hline Set up & Content \\
\hline A1 & Control (ofww only) \\
\hline A2 & Morganella morganii + ofww \\
\hline A3 & Pseudomonas xiamenensis + ofww \\
\hline A4 & Staphylococcus sp + ofww \\
\hline A5 & Chryseobacterium cucumeris + ofww \\
\hline
\end{tabular}

Table.2 Biodegradation of PAHs by Single Isolates (Bacterium)

\begin{tabular}{|c|c|c|c|}
\hline Treatments & Initial (Day 1)(mg/l) & Final (Day 21)(mg/l) & \% Removal \\
\hline & & & \\
\hline Control (ofww) & 101.72992 & 75.40663 & 25.9 \\
\hline Morganella morganii + ofww & 101.72992 & 35.50295 & 65.1 \\
\hline Pseudomonas xiamenensis + ofww & 101.72992 & 22.23959 & 78.1 \\
\hline Staphylococcus $\mathbf{s p}+$ ofww & 101.72992 & 27.31228 & 73.2 \\
\hline Chryseobacterium cucumeris + ofww & 101.72992 & 34.98499 & 65.6 \\
\hline
\end{tabular}

KEY: offw= oilfield wastewater

Fig.1 Phylogenetic tree showing the evolutionary distance between the bacterial Isolates

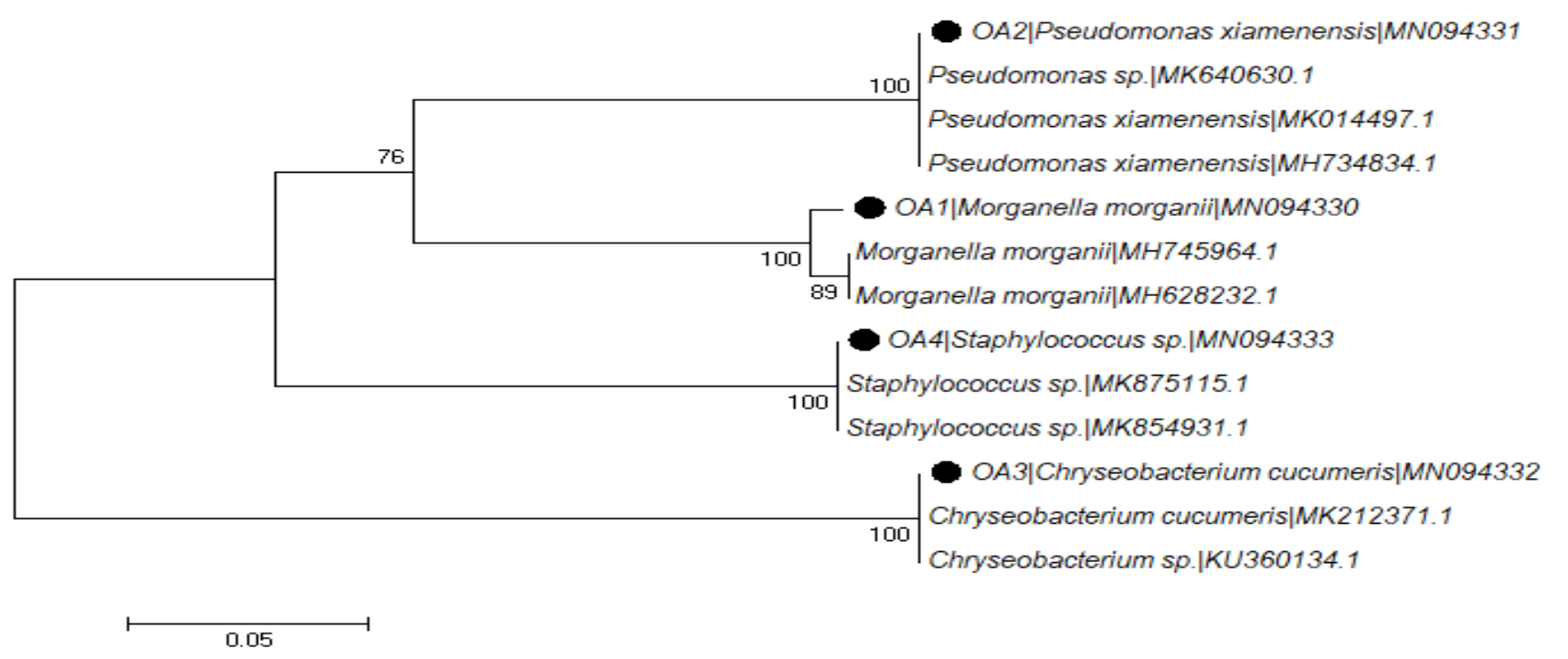


Table.3 Biodegradation of TPHs by Single Isolates (Bacterium)

\begin{tabular}{|c|c|c|c|}
\hline Treatments & Initial (Day 1)(mg/l) & Final (Day 21)(mg/l) & \% Removal \\
\hline Control (ofww) & 342.89053 & 240.74905 & 36.9 \\
\hline Morganella morganii + of ww & 342.89053 & 129.47221 & 66.1 \\
\hline Pseudomonas xiamenensis + ofww & 342.89053 & 119.29648 & 68.8 \\
\hline Staphylococcus $\mathbf{s p}+$ ofww & 342.89053 & 85.04915 & 77.7 \\
\hline Chryseobacterium cucumeris + ofww & 342.89053 & 58.18741 & 84.8 \\
\hline
\end{tabular}

KEY: offw $=$ oilfield wastewater

Fig.2 Biodegradation of PAH by single bacterium (Morganella morganii, Pseudomonas xiamenensis, Staphylococcus sp and Chryseobacterium cucumeris)

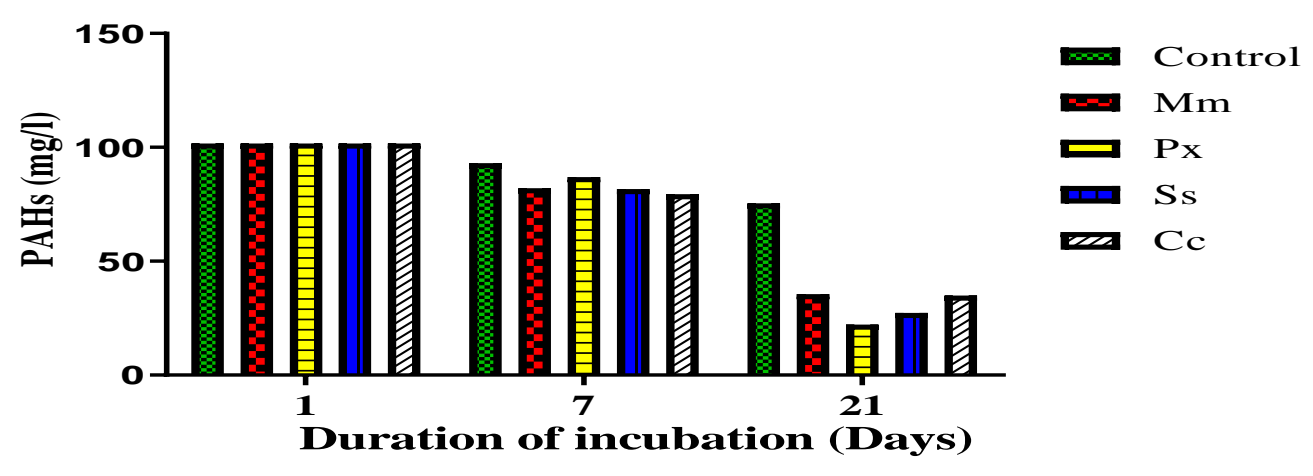

Fig.3 GC profile showing the polycyclic aromatic hydrocarbon (PAH) on Day 1

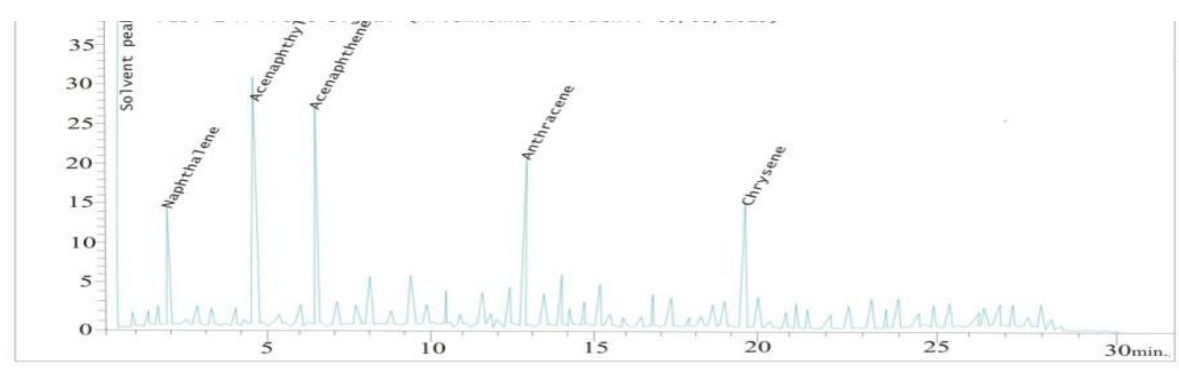

Fig.4 GC profile showing the biodegradation of polycyclic aromatic hydrocarbon (PAH) by the control on day 21

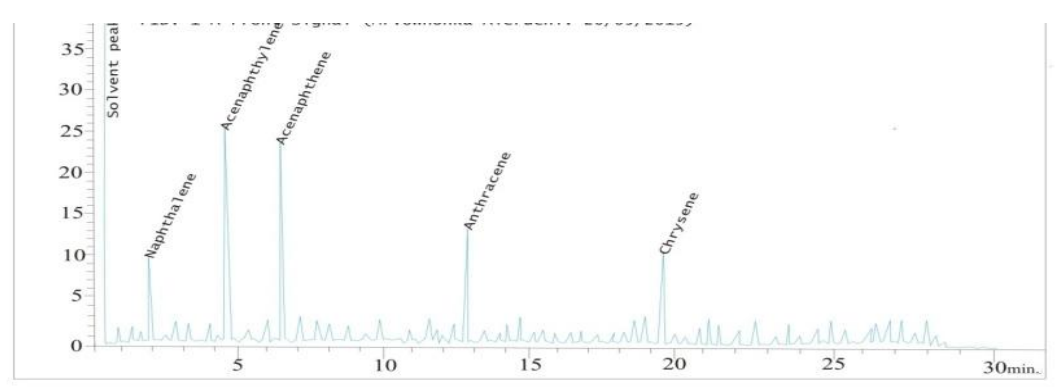


Fig.5 GC profile showing the biodegradation of PAHs by Morganella morganii on day 21

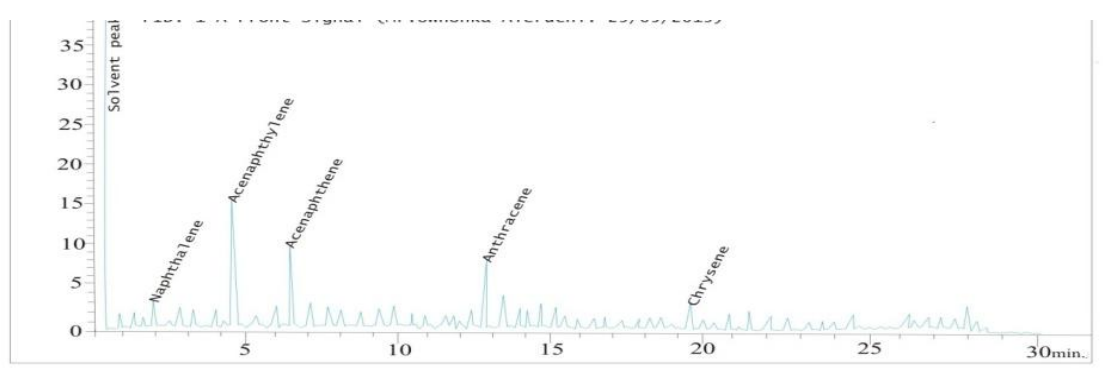

Fig.6 GC profile showing the biodegradation of PAH by Pseudomonas xiamenensis on day 21

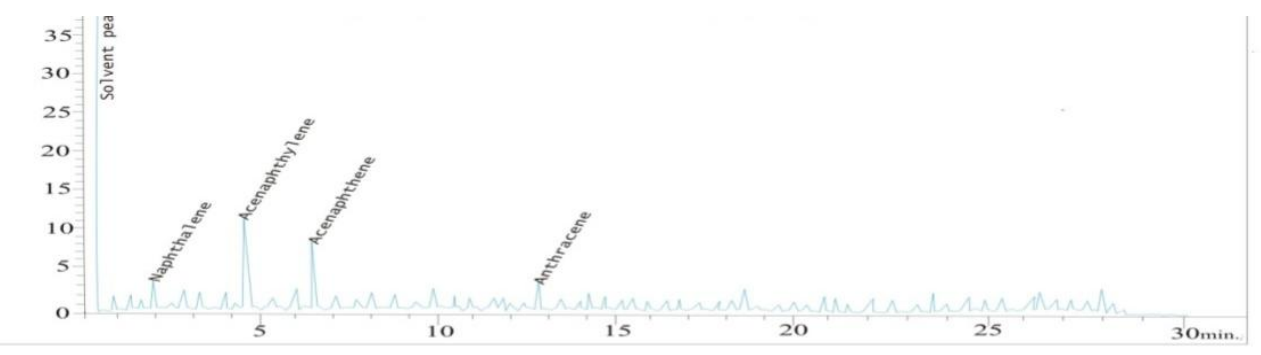

Fig.7 GC profile showing the biodegradation of Staphylococcus sp PAHs by on day 21

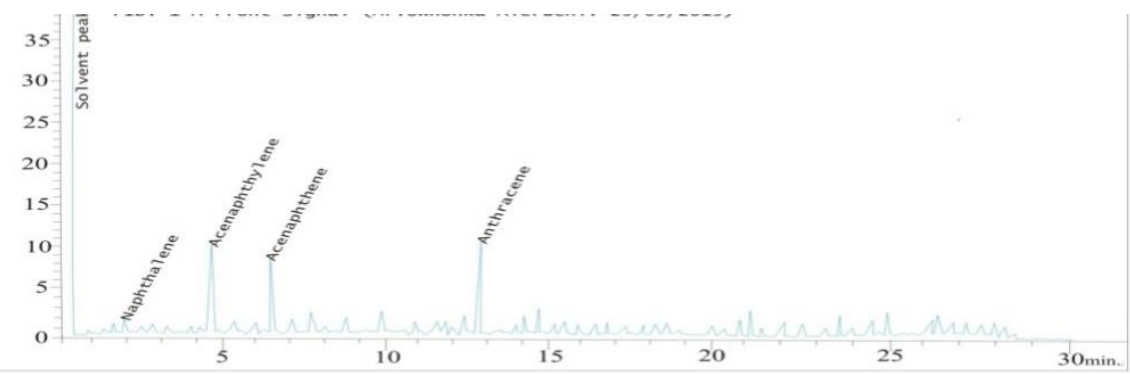

Fig.8 GC profile showing the biodegradation of PAHs by Chryseobacterium cucumeris on day 21

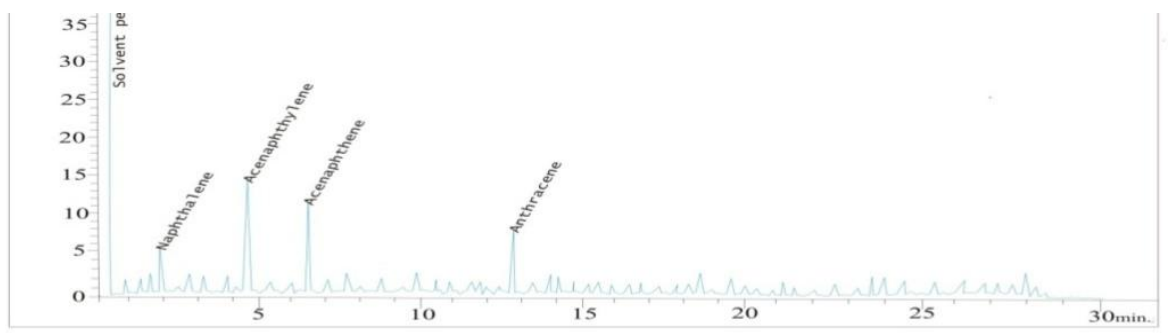


Fig.9 Biodegradation of TPH by single bacterium (Morganella morganii, Pseudomonas xiamenensis, Staphylococcus sp and Chryseobacterium cucumeris)

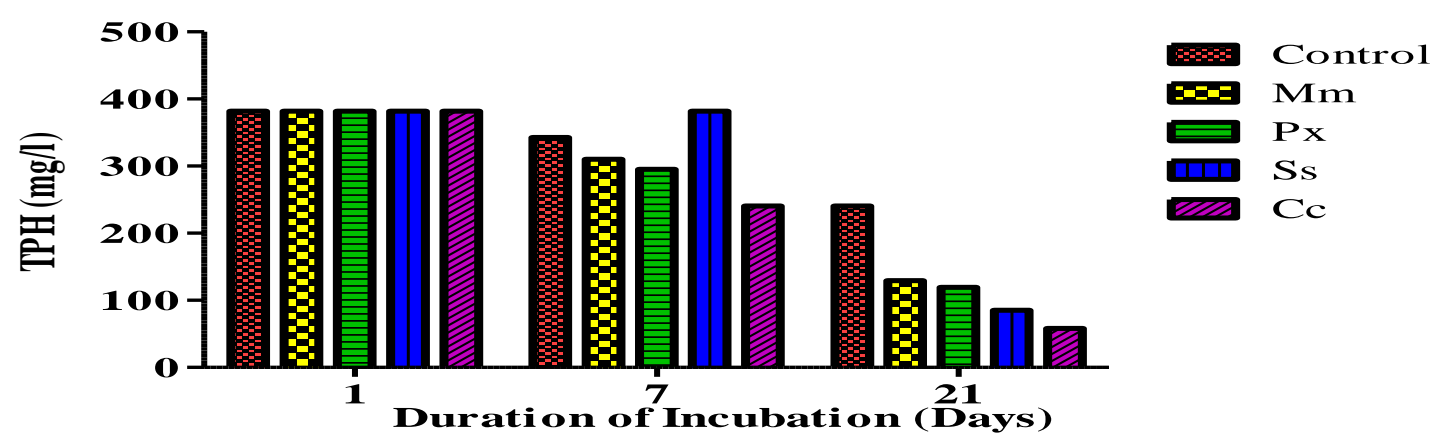

Fig.10 GC profile showing the total petroleum hydrocarbon (TPH) of the control on day 1

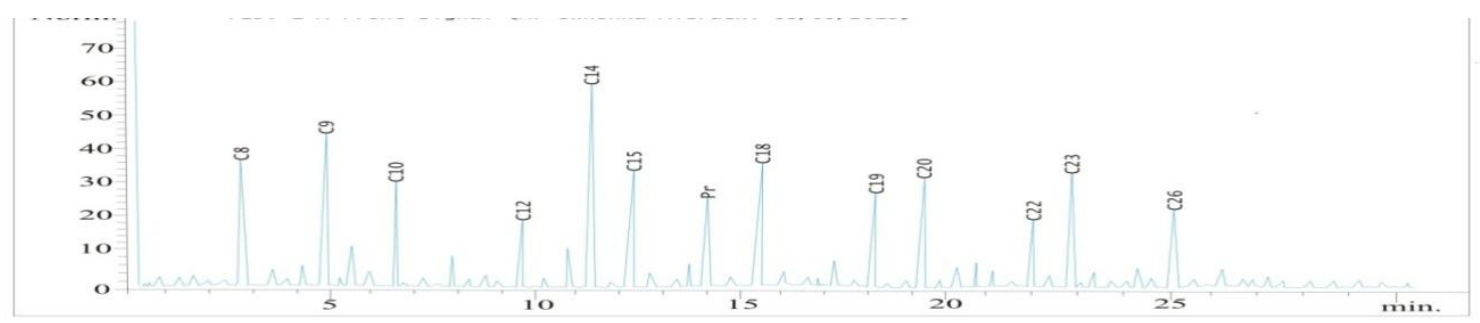

Fig.11 GC profile showing the biodegradation of total petroleum hydrocarbon (TPH) by the control on day 21

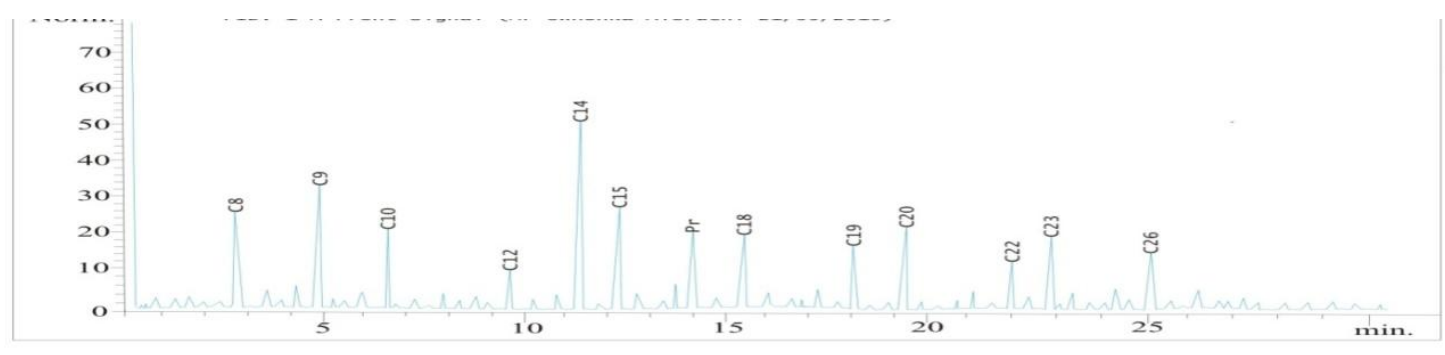

Fig.12 GC profile showing the biodegradation of TPH by Morganella morganii on day 21
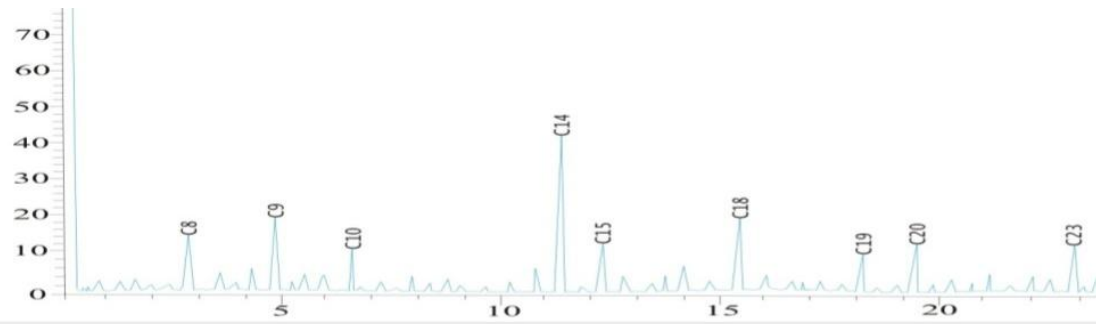
Fig.13 GC profile showing the biodegradation of TPH by Pseudomonas xiamenensis on day 21

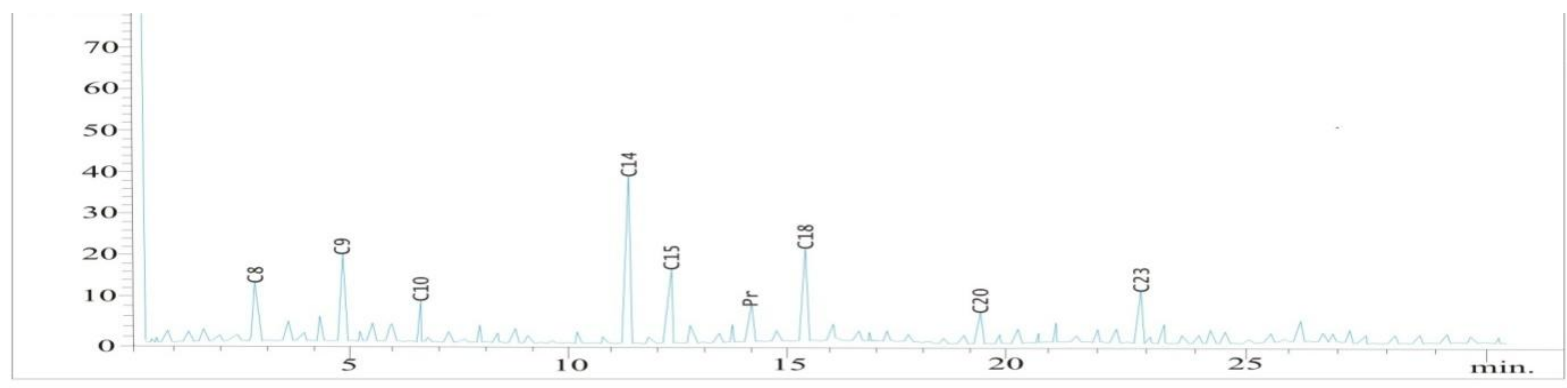

Fig.14 GC profile showing the biodegradation of TPH by Staphylococcus sp on day 21

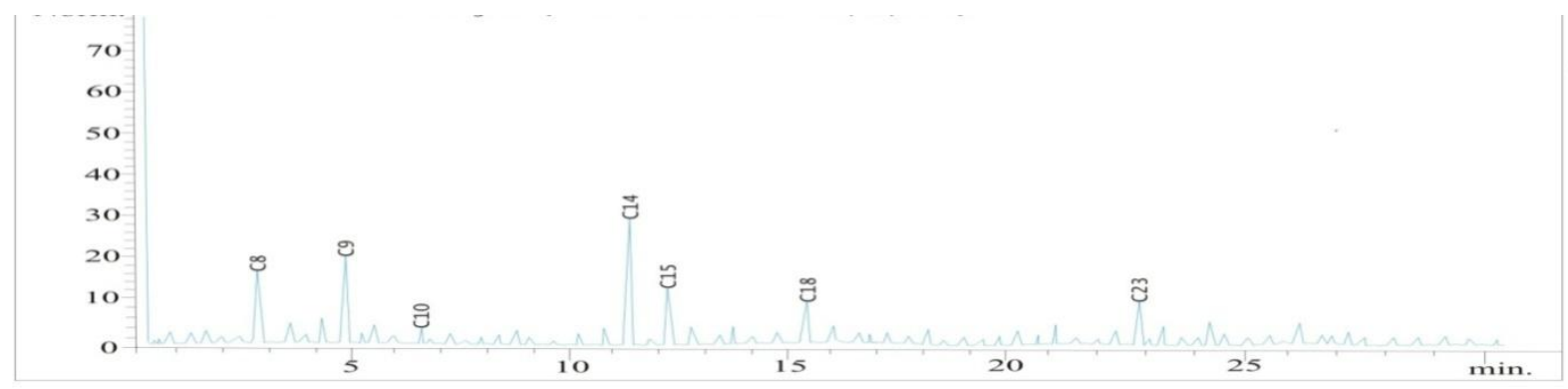

Fig.15 GC profile showing the biodegradation of TPH by Chryseobacterium cucumeris on day 21

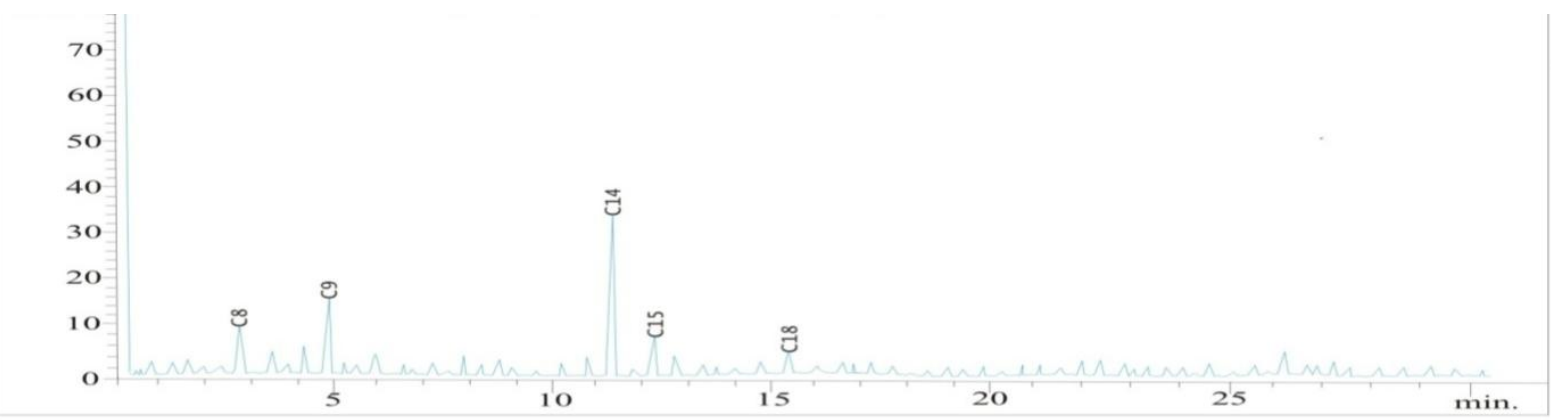

On day 7, the biodegradation of total observed in the treatment with petroleum hydrocarbon recorded least Chyrseobacterium cucumeris. The control on remaining in the treatment with day 21 did not show any clearance of the Chyrseobacterium cucumeris which was individual $\mathrm{n}$ alkane but removal most $\mathrm{n}$ followed by Pseudomonas xiamenensis, alkanes were observed in other treatment Morganella morganii, control and Staphylococcus sp. Staphylococcus sp did not reduce the total petroleum hydrocarbon on day 7 however it recorded the second best in the reduction of total petroleum hydrocarbon on day 21 , while the best or least reduction was options. Chrseobacterium cucumeris showed more clearance of the $\mathrm{n}$ alkane which was followed by Staphylococcus sp. Comparing the degradative capabilities of the individual isolates to biodegrade polycyclic aromatic hydrocarbon and total petroleum hydrocarbon. 
It was observed that Chryseobacterium cucumeris biodegraded polycyclic aromatic hydrocarbon and total petroleum hydrocarbon simultaneously on day 7 , the degradation was more on total petroleum hydrocarbon but slowed in the polycyclic aromatic hydrocarbon. Staphylococcus sp on day $7 \mathrm{did}$ not attack the total petroleum hydrocarbon but degraded polycyclic aromatic hydrocarbon.

On day 21, Staphylococcus sp recorded the second best in the degradation of both polycyclic aromatic hydrocarbon and total petroleum hydrocarbon.

Pseudomonas xiamenensis on day 7 degraded total petroleum hydrocarbon better than polycyclic aromatic hydrocarbon but degraded polycyclic aromatic hydrocarbon better than total petroleum hydrocarbon on day 21 . Morganella morganii also degraded both polycyclic aromatic hydrocarbons and total petroleum hydrocarbon but was not recorded among the first or second best degraders. Biodegradation of PAHs and TPH by single bacterium showed significant reduction in the amount of PAHs and TPH remaining at the end of the experiment. The significant reduction could be as a result of the enzymes, degradation gene they possess or their abilities to absorb them into their cytoplasmic membranes. This is in agreement with the reports of Alexander (1999) and Mandri and Lin (2007) that microorganisms degrade hydrocarbon compounds by using enzymes in their metabolisms. It is interesting to note that most of the bacterium used in this study has little or no report on biodegradation as compared to well documented hydrocarbon degraders. There has been wide report on the biodegradation ability of Pseudomonads (Elborai et al., 2016; Rahman et al., 2003; Cameotra and Singh, 2008).

However the Pseudomonas xiamenensis in this study has not been reported.
Staphylococcus sp generally has been reported as strong primary utilizers and has potential for biodegradation ability (Unell, 2008). Little is known about the biodegradation potential of Chryseobacterium cucumeris, this study shows their ability to biodegrade PAHs and TPH. Biodegradation ability of Morganella morganii has been reported by Arunagiri and Sangeetha (2015).

This study demonstrated the potentials of single bacterium cultures, in the biodegradation of PAHs and TPH. The results showed their individual capabilities which could be attributed to the degradative gene or enzymes they produce.

Microorganisms isolated from soil enriched with oilfield wastewater could be useful in determining the level of pollution in such an environment as shown in this study and thus, can be employed in the biodegradation of polycyclic aromatic hydrocarbon and total petroleum hydrocarbon in the environment.

\section{References}

Aleruchi, O. and Abu, G.O. (2015). Aerobic biodegradation of petroleum hydrocarbons in laboratory contaminated groundwater. British Microbiology Research Journal, 7(6), 313-321.

Aleruchi, O. and Obire, O. (2018). Quality characteristics of an oilfield produced water and its recipient discharge pond. E-Journal of Science and Technology, 13(4), 1-10.

Alexander, M. (1999). Biodegradation and Bioremediation. 2 edition; Academic Press, San Diego, Calif, USA. Pp. 262287.

Atlas, R. M. (1981). Microbial degradation of petroleum hydrocarbons: an environmental perspective. Microbiology Review, 45, 180-209. 
Avramidisa, P., Nikolaoua, K. and Bekiarib, V. (2015). Total organic carbon and total nitrogen in sediments and soils: A comparison of the wet oxidationtitration method with the combustioninfrared method. Agricultural Science and processing technology,4, 425-430.

Bay, S., Jones, B. H., Schiff, K. and Washburn, L. (2003). Marine Environmental Research, 56, 205-223.

Bossert, I. and Bartha, R. (1994). The fate of petroleum in soil ecosystems. In: Atlas R.M. (ed). Petroleum Microbiology. MacMillian Publishing CO., New York. Pp. 435-474.

Callot, H. and Ocampo, R. (2000). Wetlands and Water Pollution. Boston coll. Environmental Affair Law Review, 23, $885-919$.

Cameotra, S.S. and Singh, P. (2008). Bioremediation of oil sludge using crude biosurfactants. International Biodeterioration and Biodegradation, 62(3), 274-280.

Chikere, C.B., Okpokwasili, G.C. and Chikere, B.O. (2009a). Bacterial diversity in tropical crude oil polluted soil undergoing bioremediation. African Journal of Biotechnology, 8, 2535-2540.

Cui, Z., Lai, Q., Dong, C. and Shao, Z. (2008). Biodiversity of polycyclic aromatic hydrocarbon degrading bacteria from deep sea sediments of the middle Atlantic ridge. Environmental Microbiology, 10, 2138-2149.

El-Borai, A. M., Khaled, M. E., Alaa, R. M. and Samy, A. E. (2016). Biodegradation of industrial oil polluted wastewater in Egypt by bacterial consortium immobilized in different types of carriers. Pollution Journal of Environmental Studies, 25(5), 1901-1909.

Fernandez, L., Breidenstein, E. B. and Hancock, R. E. (2011). Creeping baselines and adaptive resistance to antibiotics. Drug resist update, 14(1), 21-31.

Getler, C., Gerdts, G., Timmis, K.N., Yakimov, M.M. and Golyshin, P.N. (2009a). Polutions of heavy fuel oil degrading marine microbial community in presence of oil sorbent materials. Journal of Applied Microbiology, 107, 590-605.

Jukes, T. H. and Cantor, C. R. (1969). Evolution of protein molecules. In Munro HN, editor, Mammalian Protein Metabolism, pp. 21-132, Academic Press, New York.

Kaplan, C.W. and Kitts, C. L. (2004). Bacterial succession in a petroleum land treatment unit. Applied Environmental Microbiology, 70, 1777-1786.

Mandri, T. and Lin, T. (2007). Isolation and Characterization of engine oil degrading indigenous microorganism in Kwazulu- Natai South Africa. African Journal of Biotechnology, 61, 23-27.

Obire, O., Aleruchi, O. and Wemedo, S. A. (2020). Fungi in biodegradation of polycyclic aromatic hydrocarbons in oilfield wastewater. Acta Scientific Microbiology, 3(4), 220-224.

Okpokwasili, G. C. and Amanchukwu, S.C. (1988). Petroleum hydrocarbon degradation by Candida species. Environment International, 14: 243247.

Prescott, L. M., Harley, J. P. and Klien, D. A. (2005). Microbiology. $6^{\text {th }}$ ed. McGraw Hill London. Pp. 135-140.

Prince, R. (1993). Petroleum spill bioremediation in marine environment. Critical Review of Microbiology, 19, 217-242.

Prince, R. and Atals, R.M. (2005). Bioremediation of marine oil spills. In: Atlas, R.M, Philip, J. editors. 
Bioremediation: applied microbial solutions for real world environmental cleanup. Washington, DC: American Society for Microbiology (ASM) Press; 269-292.

Rahman, K. S.M., Rahman, T. J., Kourkoutas, Y., Petsas, I., Marchant, R. and Banat, M. I. (2003). Enhanced bioremediation of $\mathrm{n}$-alkane in petroleum sludge using bacterial consortium amended with rhamnolipid and micronutrients. Bioresource Technology, 90(2),159168.

Saitou, N. and Nei, M. (1987). The neighborjoining method: A new method for reconstructing phylogenetic trees. Molecular Biology and Evolution, 4,
406-425.

Suleimanov, A.Y. (1995). Conditions of waste fluid accumulation at petrochemical and processing enterprise prevention of their harm to water bodies, Meditsina Truda Promyswe Nnaia Ekologila. 12: 31-36.

Unell, M. (2008). Physiological genetic and proteomic characterization of Arthrobacter chlorophenolicus during growth on different phenolic substrates or temperature. A PhD. Thesis submitted to the department of microbiology, Faculty of Natural Resource and Agricultural Science, Swedish University of Agricultural Science, Uppsala.Pp.1-265.

\section{How to cite this article:}

Aleruchi, O. and Obire, O. 2021. Capabilities of Pure Culture of Bacteria in the Biodegradation of Polycyclic Aromatic Hydrocarbons and Total Petroleum Hydrocarbons in Oilfield Wastewater. Int.J.Curr.Microbiol.App.Sci. 10(03): 810-822. doi: https://doi.org/10.20546/ijcmas.2021.1003.084 